\title{
Female directorship on boards and corporate sustainability policies: Their effect on sustainable development
}

\begin{abstract}
We aim to explore whether board gender diversity, specifically women institutional directors, improves the sustainability development and stakeholder engagement of listed firms by affecting corporate social responsibility (CSR) policies. Moreover, within female institutional directors we can differentiate between banks and insurance companies (pressure-sensitive female institutional directors) and mutual funds, investment funds, pension funds and venture capital firms (pressure-resistant female institutional directors). Thus, the effect of these categories of directors on CSR policies is also analysed. Our findings suggest that female institutional, as a whole, have a positive effect on CSR policies, the same behaviour that show pressure-resistant female institutional, while pressure-sensitive institutional do not impact on CSR policies. This research provides a new framework for the role played by certain types of female directors (female institutional directors, female pressure-sensitive directors and female pressure-resistant directors) in CSR policies and, thus, may help policymakers to promote CSR policies, and to take action to promote responsible behaviour among listed firms.
\end{abstract}

\section{INTRODUCTION}

The rapid globalization process under way in the 21st century has placed companies in a new stage in which they are more aware of promoting socially responsible behaviour. If firms want to survive in today's very competitive environment, they have to adapt to the global economy, and as a consequence, they have increased their interest in the social and environmental dimensions of business. According to Nieto and Fernández (2004), there is a trend characterized by the creation of economic, social and environment value in the short and long term, which contributes to sustainable development. In other words, corporate social responsibility (CSR) includes all business decisions that go beyond the economic interests of the firm. This line of thinking is also supported by the Spanish Code of Good Corporate Governance of listed firms, known as the Conthe Code (2006), updated in 2015.

Previous literature (Correa et al., 2004; Andrés, 2005) has emphasized that CSR should not be confused with philanthropy. According to Carroll (1996), philanthropy is one of four essential components of a responsible company, the other three being economic, legal and ethical aspects. In this regard, the term CSR covers a very broad concept which encompasses philanthropy, among other dimensions. This leads us to define CSR, for which we draw on the definition given in the Green Paper of the European Commission (2001, p.7), which states that CSR is "a concept whereby companies integrate social and environmental concerns in their business operations and in their interaction with their stakeholders on a voluntary basis". In others words, it is "a concept under which companies decide voluntarily to contribute to a better society and a cleaner environment" (European Commission, 2001, p. 
4). As noted by Santos (2011), such a definition of CSR combines diverse objectives that must be integrated in the management process and that go hand in hand with the objective of achieving positive economic outcomes. Seoane (2006) argues that the first level of firm responsibility is to be sustainable over the long term, i.e. that the firm must generate sufficient profits while respecting the law. However, some authors (e.g. Freeman, 1984; Morsing and Schultz, 2006) support the idea that firms must be responsible to all of their stakeholders as their activity not only has consequences for those internal to the firm, but also for third parties. Therefore, although the first step in integrating CSR is to be sustainable over the long term, the firm must also consider broader social and environmental dimensions. The importance of firms' social practices has generated a demand for information to determine how ethical companies are. Public reports on CSR are essential to identify which companies are or are not responsible (Moneva and Llena, 1996).

Adams (2002) and Waddock (2003) argue that firms are interested in adopting CSR as a business management model, because they can develop systems and policies based on the benefits to the company and its stakeholders. Sánchez-Ballesta and García-Meca (2007) show that corporate governance mechanisms generate corporate behaviour that influences CSR policy. There are many firm characteristics that may affect the level of CSR performance, such as board structure (Ballesteros et al., 2015), financial performance (Waddock and Graves, 1997), liquidity (Küger, 2009), profitability (Aupperle et al., 1985) and firm size (Harjoto and Jo, 2011), among others. The prior literature (Ballesteros et al., 2015; Goodstein et al., 1994; Pfeffer, 1972) places specific emphasis on the effect of the board on determining CSR in companies, with particular reference to size and board composition, for example in terms of independence. Matten and Moon (2008) and Miras-Rodríguez et al. (2013), among others, also highlight that cultural, legal and political aspects may affect the firm when making decisions about CSR. However, little attention has been paid to other board characteristics, such as institutional directors and board gender diversity, although this is changing. This view is supported by Abbott and Monsen (1979) and Ricart et al. (2005), who argue that examining the impact of board composition on CSR disclosure is a growing trend.

In the last 20 years, institutional directors who represent investors such as pension funds, insurance companies and banks have increased their influence on financial markets as they have abandoned their former passive role on company boards (Wen, 2009). According to López-Iturriaga et al. (2015), institutional directors play an essential role in monitoring managers. Moreover, previous research demonstrates that these directors have effect on leverage (David et al., 2001), financial reporting quality (Ajinkya et al., 2005; Pucheta- 
Martínez and García-Meca, 2014) and firm performance (García-Meca and Pucheta-Martínez, 2015), inter alia. Furthermore, institutional directors have been increasing their activism concerning CSR, trying to integrate social, ethical and environmental matters in their businesses (Wen, 2009). In addition, previous literature (Zahra et al., 2000) has shown the importance of not considering institutional directors as a homogeneous group. In this regard, it is important to distinguish between pressure-sensitive institutional directors, who maintain both an investment and business relationship with the firm, and pressure-resistant institutional directors, who only maintain an investment relationship with the company.

Turning to board diversity, this may imply many differing opinions and ideas, which may affect CSR policy, as a firm's stakeholders are not a homogeneous group (Catalyst, 1995). The more diverse a firm's board, the easier it should be to understand the needs and desires of the stakeholders, who are also heterogeneous (Van der Walt and Ingley, 2003; Ayuso and Argandoña, 2007). Moreover, authors such as Carter et al. (2003) and Van der Walt and Ingley (2003), among others, posit that board diversity may have positive consequences for innovation and creativity. Board diversity can be measured by nationality, gender, age and ethnicity, inter alia (Campbell and Mínguez-Vera, 2007). Within these board characteristics, gender diversity needs to receive more attention by researchers, as women directors are characterized by their empathy, communication skills, participation and cooperation (Eagly et al., 2003; Ballesteros et al., 2015). Such attributes may be reflected in greater concern for social and environmental matters and thus they may have a positive impact on CSR reporting (Harrigan, 1981; Kesner, 1988). According to Carter et al. (2003) and Campbell and Mínguez-Vera (2008), board gender diversity fosters good corporate practice and improves the quality of financial reporting, as well as other aspects of CSR.

The roles played by institutional and women directors on company boards and the scant attention paid by prior research to the association between these directors and CSR encouraged us to analyse how institutional directors and female institutional directors on boards affect CSR reporting. Thus, our study tries to fill a gap in the literature. As far as we know, this paper is the first to analyse the effect of female institutional directors on CSR reporting, as well as to examine the relationship by distinguishing between pressure-resistant female institutional directors, i.e. investment funds, pension funds and mutual funds, and pressure-sensitive female institutional directors, i.e. insurance companies and banking institutions, as they may behave differently.

This paper contributes to the literature in several respects. First, our evidence reinforces the view that female institutional directors protect the interests not only of 
shareholders, but also of all stakeholders of the firm. Second, we fill the gap in prior research concerning the role played by female institutional directors in firms' CSR policies, showing that female institutional directors cannot be considered a uniform group because pressureresistant and pressure-sensitive institutional directors behave differently with respect to CSR reporting. Third, the paper highlights the relevance of having female institutional directors and pressure-resistant female directors on boards due to their engagement with CSR matters. Finally, our analysis provides a new index that measures the level of CSR disclosure of the firms, which may be useful for nongovernmental organizations (NGOs), CSR observatories, practitioners and researchers in determining which companies are or are not socially responsible.

The paper proceeds as follows: in section 2, we focus on the institutional setting; section 3 describes the theoretical background to the study and develops hypotheses; section 4 describes the sample, methodology and variables used in the study; section 5 provides the analysis and discusses the findings; the final section discusses the conclusions, the limitations inherent to this study and future lines of research.

\section{INSTITUTIONAL SETTING}

In the last few decades, Spain has increased its interest in CSR policies because society is pressing companies to engage in sustainable production. For this reason, a growing number of CSR reports, guidelines, observatories, studies, indicators and indexes have exerted an influence in changing the Spanish business culture.

The Spanish Conthe Code, issued in 2006, and revised in 2015, is a key aspect of this change. The Conthe Code (2015) provides three specific recommendations concerning CSR and another four that integrate CSR in other aspects of firms. The first of the three specific recommendations makes reference to the inclusion of CSR policy with corporate governance rules and internal codes of conduct to be supervised by a committee. The second refers to the minimum subject matter to be included in the CSR policy. In particular, the CSR policy must include reference to specific practices on issues related to shareholders, employees, customers, suppliers, social and environmental matters, diversity, fiscal responsibility, respect for human rights and prevention of illegal behaviour and the monitoring mechanisms for financial risk, ethics and business conduct. The third states that CSR issues must be reported in the management report, or in a separate report, using any of the different internationally accepted methodologies. 
The four recommendations make reference to various matters. The first refers to the CSR report, which must be published on the website of listed firms in advance of the Annual General Meeting. The second states that the board of directors must try to conciliate the social interest with the interest of its employees, suppliers, customers and other stakeholders who may be affected by the activity of the company. Furthermore, the impact of the firm's activities on the community and the environment must also be considered. The third recommendation is that the policy for the recruitment of directors promotes that the number of women on the board represents at least $30 \%$ of the board directors. The last highlights that the policies of control and risk management must identify different types of risk (financial and non-financial) that the firm faces.

Spanish listed firms (from 2016) have to report on their checking of adherence to the different aspects of the code and this includes CSR issues contained in the corporate governance annual reports. The implication of this increase in the proposal of principles and recommendations in CSR matters is the need for the promotion of ethical and responsible behaviour by firms. CSR policies provide a guide for the action of boards of directors in terms of transparency and good governance.

Spanish corporate governance is a characterized by low independence of boards, a lack of active market control, the presence of large shareholders on boards, a low level of development of capital markets, high ownership concentration and family ownership, a onetier board system and a low level of legal protection for investors and pyramidal groups (Sánchez-Ballesta and García-Meca, 2005). In this context, dominant shareholders take important positions on Spanish listed firms' boards and exert a strong influence on the management due to the high ownership concentration. Institutional investors are among the most important controlling shareholders in Spain and consequently they have an important influence on corporate governance (Crespí et al., 2004). Indeed, Spanish boards of listed firms are characterized by having $40 \%$ institutional directors, the highest percentage of European countries (Heidrick and Struggles, 2011). Large banks are some of the most significant controlling shareholders of Spanish listed firms and their representatives sit on boards as relevant directors.

Finally, another aspect to consider is board gender diversity. Nowadays, the role of gender diversity on boards is gaining relevance and this fact is reflected in the Spanish corporate governance codes. More concretely, the Conthe Code (CUBG, 2006) promotes board gender diversity, recommending that firms include women directors on their boards so that the presence of men and women is balanced. Furthermore, the revised version of this 
code in 2015 recommends reaching a gender quota on boards of listed firms of $30 \%$ women by 2020. In this vein, Act 3/2007 of 22 March for Effective Equality between Women and Men (LOIMH, 2007) also proposed achieving a gender quota on boards of listed firms of $40 \%$ women by 2015 . These recommendations have encouraged the presence of female directors on boards of Spanish listed firms, but it is still far from the level reading in other countries such as Germany and the Netherlands, among others. In addition, most female directors on Spanish boards of listed companies are institutional directors (Mateos et al., 2010). Moreover, as our descriptive figures report, among institutional female directors, the proportion of pressure-resistant female directors is greater than that of pressure-sensitive female directors. This is in line with López-Iturriaga et al. (2015) and Manzaneque et al. (2016), who find that the percentage of pressure-resistant directors on Spanish boards of listed firms is higher than that of pressure-sensitive directors.

\section{THEORETICAL BACKGROUND AND HYPOTHESES}

Stakeholder theory posits that firms should consider all the stakeholders that may affect or be affected by the company's activities (Freeman, 1984). This theory supports a framework mediating between business ethics and organizational management, as a result of which firms have to take into account not only their shareholders, but also a wider range of stakeholders, such as customers, the local community and employees, among others. Therefore, firms have to attend not only to their economic responsibilities, but also the stakeholders' interests.

Most sustainable management research is based on the stakeholder perspective (Kolk and Pinkse, 2007; Sarkis et al., 2010; Husted and Allen, 2011; Lee, 2011; Perez-Batres et al., 2012; Yamahaki, 2013; Montiel and Delgado-Ceballos, 2014). Ayuso and Argandoña's (2007) paper, also focusing on the stakeholder approach, argues that the board of directors' role as defenders of the interests of shareholders has changed. To the extent that boards are responsible for setting the values and standards within organizations, companies interested in integrating CSR policies and addressing the interests of different stakeholders may have to adapt their board composition and functioning to this new role. Authors such as Siebens (2002), Matsumura and Shin (2005) and Arjoon (2008) support the notion that directors have to demonstrate greater ethical responsibility in the way they run firms as society is pressuring them following the numerous scandals that came to light in the wake of the economic crisis. This idea is also supported by Luoma and Goodstein (1999), who based on stakeholder theory, argue the relevance of populating boards with directors who have an ethical attitude 
when conducting business, because they represent not only the shareholders, but also the other stakeholders of the firm, and because a change in corporate governance laws and the legal system, promoting this approach, has taken place in the last few decades.

Institutional directors are receiving attention from academic researchers (Black, 1992; Baums et al., 1993; Gillan and Starks, 2000; Xiangqian, 2002; Bhojraj and Sengupta, 2003) due to the monitoring role they play in sitting on boards, their active behaviour in response to the corporate governance problems of firms (Brickley et al., 1988; Pucheta-Martínez and López-Zamora, 2015) and their capacity as disciplinary managers (Lee and Roberts, 2015). Furthermore, Lee and Roberts (2015) argue that such directors have many incentives "to prefer firms with better corporate governance mechanisms". Thus, it is logical to consider that firms with institutional directors on boards will be more likely to be transparent, and hence, encourage CSR reporting as the costs associated with their monitoring role will be lower in responsible companies. This argument is supported by previous research (Xie et al., 2003; Charitou et al., 2007; Ljungqvist et al., 2007; Wan-Hussin 2009), which shows that institutional directors raise corporate transparency and reduce fraudulent accounting practices, inter alia. Furthermore, authors such as Zahra et al. (1993), Johnson and Greening (1999), Webb (2004) and Harjoto and Jo (2011) suggest that institutional directors tend to be more aware of social and environmental demands, taking responsibility in these areas. In other words, these directors take an active role, and thus, may influence CSR reporting as they are interested in their reputation.

Agency theory also argues that institutional directors have incentives to act independently of managers, and therefore, they will protect the interests of the shareholders to mitigate agency costs (Brickley et al., 1988; Chung et al., 2002; Bhojraj and Sengupta, 2003; Abd-Elsalam and El-Masry, 2008; Colpan and Yoshikawa, 2012). In addition, Mahapatra (1984) shows that CSR policy is a long-term responsibility of the firm, and thus, companies with institutional directors, who are usually associated with a long-term orientation, will be more likely to have better accounting and CSR practices (Hill and Snell, 1988). In this vein, the prior literature (Cox et al., 2004, Neubaum and Zahra, 2006; Zattoni, 2011) shows that institutional directors exert a positive impact on CSR disclosure.

Besides the significant impact of institutional directors on CSR policy, it is also relevant to analyse the role played by female institutional directors. Previous evidence reports the importance of including women on boards as they have a positive impact on financial reporting quality (Campbell and Mínguez-Vera, 2008), fostering good corporate practice (Carter et al., 2003), influencing the talent available for the "highest management and 
oversight functions" (European Commission, 2011) and contributing to the creation of a satisfactory environment on boards (Liao et al., 2015). In this sense, women on boards enhance the firm's governance. According to Donaldson and Davis (1991), based on stakeholder theory, women directors help to enhance the association among all the stakeholders of companies. Moreover, Luoma and Goodstein (1999) argue that gender diversity on boards may have a positive effect on transparency and fair decisions.

Furthermore, Eagly (1987) suggests that men and women exhibit different behaviour in business due to the different roles they play in society because of stereotypes and beliefs. Bakan (1966) also argues that women are more communal than men as they are associated with "traits such as empathy, caring, great concern for others and being interested in actualising values in relationships of great importance to community". Similarly, authors such as Bilimoria and Piderit (1994), Shrader et al. (1997), Williams (2003) and Zelechowski and Bilimoria (2006) demonstrate that women exhibit more socially sensitive behaviour than men, and therefore, female directors will be more likely to disclose CSR information. Female directors are posited to be more committed to environmental and social issues than men, and thus, are likely to accept CSR responsibilities on the boards of firms (Liao et al., 2015). In this line, authors such as Barako and Brown (2008) and Prado-Lorenzo and García-Sánchez, (2010) show that women's behaviour in business is associated with greater transparency, especially in CSR matters. Therefore, extending preceding views concerning gender diversity on boards, we predict that female institutional directors will have a positive impact on CSR disclosure.

Based on above arguments, we posit the following two hypotheses:

$\mathrm{H}_{1}$ : CSR is positively affected by female institutional directors.

Prior research (Almazan et al., 2005; Borokhovich et al., 2006; Ferreira and Matos, 2008; Ramalingegowda and Yu, 2012) shows that institutional directors do not behave in a monolithic way, as they represent institutional investors who may or may not maintain business ties with the firm in which they invest, and therefore, they may have different attitudes with regard to anti-takeover amendments, CEO compensation and CSR policy, inter alia. They can be separated into two groups: pressure-sensitive institutional directors (banks and insurance firms) and pressure-resistant institutional directors (mutual funds, investment funds, pension funds and venture capital firms) (Bhattacharya and Graham, 2007; Dong and Ozkan, 2008; Pucheta-Martínez and López-Zamora, 2015). 
Pressure-sensitive institutional investors tend to maintain both business and investment links with companies, and as a result, to safeguard these links, they may not be disposed to confront management decisions. This view is supported by Almazán et al. (2005), who show that pressure-resistant directors can provide more intense managerial monitoring than pressure-sensitive investors because they are more active. Past literature (Starks, 1987; Finkelstein, 1992; David et al., 1998, Almazán et al., 2005) emphasizes the hypothesis that banks and insurance companies seek their own profit because of the design of their incentives systems (Finkelstein, 1992). In this vein, Johnson and Greening (1999) find that pressuresensitive institutional directors have a short-term orientation, given their short-term profitability perspective, and therefore, these directors will try to pressure the company also to adopt this orientation. Hence, these authors suggest that such directors face more conflicts of interest due to their relationship with the firm; hence, they will be less concerned about monitoring managers, generating firm value or CSR matters, for example. This idea is consistent with Eng (1999), who also reports that insurance companies have a short-term horizon, and consequently, may not be interested in safeguarding the interests of stakeholders.

Within the category of pressure-sensitive institutional investors, banks are the most prevalent. Thus, banks become both shareholders and creditors. They may perceive that this double role gives them more information than other types of shareholders and use this information in their own interests (Gorton and Schmid, 2000). This may encourage the formation of controlling coalitions between such types of institutional investors and managers or other stakeholders, creating corporate groups to extract private benefits (Ali et al., 2007). Pressure-sensitive institutional directors will be less effective in monitoring managers, with whom they can be expected to align (Brickley et al., 1988) as they do not want to lose their business or potential business with the company. Hence, pressure-sensitive institutional directors will not press managers to behave responsibly. Therefore, pressure-sensitive institutional directors may behave in their own interests and not in the company's stakeholders' interests. As a result, they will be less likely to disclose CSR information. This supports a negative association between pressure-sensitive institutional directors and CSR reporting, consistent with the collusion hypothesis, which argues that some directors may have incentives to collude with managers because they have a short-term perspective. Consequently, they will not pressure managers to behave responsibly and CSR disclosure will decrease.

On the other hand, pressure-resistant directors, who represent institutional investors with no business links with the firm, only investment ties, such as mutual funds, investment 
funds, pension funds and venture capital firms, play a monitoring and disciplinary role on boards (Lopez-Iturriaga et al., 2015). In contrast to pressure-sensitive institutional directors, pressure-resistant directors do not face a conflict of interests as they do not maintain any business relationship with the firm. Thus, these directors are able to discipline managers and enforce responsible behaviour. Furthermore, Finkelstein (1992) argues that public pension funds and mutual funds, among others, have no "fear of retribution" from firm's managers because they can be involved in corporate governance matters without being influenced by managers.

Pressure-resistant institutional directors will prefer sustainable firms because the costs associated with monitoring managers are lower. Furthermore, Johnson and Greening (1999) find that pressure-resistant institutional directors have a positive effect on CSR issues. More concretely, these authors provide evidence that pension funds have a positive impact on product quality (which includes the environment), the community, human talent matters, gender diversity and minorities. Accordingly, given that the benefits related to CSR investment are derived over the long term, and pressure-resistant directors on boards are characterized by a long-term horizon, the integration between these directors and CSR disclosure is relevant (Graves and Waddock, 1994). This argument is also supported by Sethi (2005), who shows that pension funds play a very relevant role in corporate governance as they will try to ensure that firms have a long-term perspective, which will encourage responsible behaviour. Furthermore, Finseth (2010) and Cotter and Najah (2012) show that large institutional investors, such as pension funds, press firms on climate change issues. According to this evidence, firms these days have to be concerned about CSR matters to be competitive due to the pressure exerted by their stakeholders. Consequently, we expect that pressure-resistant institutional directors will have a positive impact on CSR matters, in line with the supervision (contest or monitoring) hypothesis, which argues that some directors have motivations to supervise management teams because they have a long-term perspective. They will be concerned for their reputation, and accordingly, will induce management to report CSR issues.

To the best of our knowledge, there is no research that has analysed the effect of pressure-sensitive and pressure-resistant female directors on CSR disclosure. Consequently, this gap in the corporate governance literature also has to be filled. Female directors show more civilized behaviour, are more risk averse, may be less sophisticated and sensitive financially and may be stricter in monitoring management and quicker to detect opportunistic behaviours than male directors, inter alia (Khazanchi, 1995; Jinakopolos and Bernasek, 1998; 
Byrnes et al., 1999). All these aspects of female behaviour may align with, or diverge from, the interests of all shareholders, depending on the kinds of institutional investors they represent on boards. Hence, based on above arguments, we can expect that pressure-sensitive female institutional directors will have a negative impact on CSR reporting, while pressureresistant female institutional directors will exert a positive impact. Therefore, we posit the following two hypotheses:

$\mathrm{H}_{2}$ : CSR is negatively affected by pressure-sensitive female institutional directors.

$\mathrm{H}_{3}$ : CSR is positively affected by pressure-resistant female institutional directors.

\section{EMPIRICAL DESIGN}

\subsection{Sample}

Our sample consists of Spanish non-financial listed firms from 2005 to 2014. Financial entities have been excluded from the sample because they comply with particular accounting rules, and thus, the comparison between their financial statements and those of non-financial companies is more complicated (La Porta et al., 2000). We have drawn an unbalanced panel dataset of 1,018 firm-year observations. According to Arellano (2003), the findings provided by an unbalanced panel are as reliable as those reported for balanced panels.

The information for constructing the CSR_Index was collected from the web page of the Global Reporting Initiative (GRI), on which the annual GRI report of companies that have voluntarily disclosed CSR information can be found. Financial and corporate governance data were obtained respectively from the financial statements and the annual corporate governance reports respectively that listed firms have to disclose in the Public Register of the Spanish Securities Market Commission (CNMV).

\subsection{Variables}

Our dependent variable, CSR disclosure or reporting, is defined as the CSR_Index and it is created using social, environmental and stakeholder information since CSR is a multidimensional concept (Maignan and Ferrell, 2004; Peloza and Shang, 2011). We base our CSR_Index on Cuadrado et al. (2015), who also focus on the three above types of information to construct their CSR disclosure measure, as do Carroll (1979) and Moneva and Llena (1996).

For each area (social, environmental and stakeholder information), a company is awarded 1 point if it reports total information, 0.5 points if the information is partial (partial 
information is when firms disclose some information, for example about environmental matters, but do not provide all the information considered to assess the area) and 0 points, otherwise. The total score for each firm (the sum of each score assigned to each of the three areas) is divided by 3 , the maximum score that firms can attain. Thus, we have classified the firms in the following way: if firms have a total score of 0 , they are not socially responsible; a score of $0.1-0.5$ indicates that they are moderately responsible; a score of $0.6-0.9$ represents an acceptable level of responsibility; a score equal to 1 indicates that firms are completely responsible.

Several independent variables are used. The variable percentage of female institutional directors, defined as WINST, is calculated as the ratio between the total number of female institutional directors on the boards of directors and the total number of directors on boards. We also consider the representatives of pressure-sensitive and pressure-resistant female institutional investors, i.e. pressure-sensitive and pressure-resistant female directors respectively. We define pressure-sensitive female directors as WSENSIT, and pressureresistant female directors as WRESIST, and they are calculated as the ratio between the total number of pressure-sensitive female directors on boards and the total number of directors on boards and the ratio between the total number of pressure-resistant female directors on boards and the total number of directors on boards, respectively.

Regarding control variables, we consider several factors that may affect the CSR_Index. First, we control for board independence (BINDEP), calculated as the ratio between the total number of independent directors on the boards of directors and the total number of directors on the boards of directors. Authors such as Zahra and Stanton (1988) and Ibrahim and Angelidis (1995) report that independent directors, due to their characteristics, are concerned about their reputation and consequently are more interested in CSR behaviour. Hence, we expect a positive sign between BINDEP and CSR reporting. Second, leverage (LEV) is measured as the ratio of the book value of debt to the total assets. Jensen and Meckling (1976) report that leverage is positively associated with CSR reporting as companies with high levels of leverage will be more likely to disclose voluntary information to reduce agency costs. We predict a positive sign for this variable. Third, we control for profitability, defined as the return on assets (ROA), and calculated as the ratio of earnings before interest and taxation (EBIT) to book assets (O'Connor, 2013). We expect a positive sign for ROA, in line with Kim et al. (2012), who find a positive association between high firm financial resources and high levels of social practices. Fourth, we control for firm size, labelled as SIZE, and measured as the log of the total assets (Aguilera et al., 2007; Bies et al., 
2007) (expressed in thousands of Euros). We predict a positive association between SIZE and CSR reporting (Jenkins, 2006; Bies et al., 2007). Fifth, we consider board size (BSIZE), measured as the total number of directors on boards. Prior literature (Kassinis and Vafeas, 2002; De Villiers et al., 2011) shows a positive relationship between board size and CSR performance.

Another control variable considered is insider ownership (INSOWN), calculated as the proportion of stocks held by inside directors, in line with Rashid (2013). We predict a negative association between insider ownership and CSR disclosure, in line with Harjoto and Jo (2011). We control for sector, calculated as a dummy variable that takes the value 1 if the firm belongs to the sector analysed and 0 , otherwise. Here, we draw on the CNMV classification, which considers the following sectors: transport, labelled TR; cement, glass and construction materials, defined as CGCM; commerce and other services, labelled COMER; construction, defined as CONST; energy and water, defined as EW; financial and insurance, labelled FININS; the chemical industry, defined as CHIN; real estate, defined as RE; mass media, measured as MASSM; basic metal industries, measured as BMI; other processing industries, measured as OPI; metal processing industries, defined as MPI; finally, the remaining sectors not included in any of the above categorizations (sectors with few firms), defined as OTHR. According to previous research (Deegan and Gordon, 1996; ArchelDomenech, 2003; García-Ayuso and Larrinaga, 2003), there are sectors that are more likely to report CSR information than others as their activities have a greater impact on society. Finally, we also control for firm and year fixed effects. Firm fixed effects capture nonobservable and constant characteristics of firms that might possibly be linked to our dependent variable.

Table 1 provides a summary of the information on the variables included.

[Insert Table 1 about here]

\section{RESULTS}

\subsection{Descriptive statistics}

Table 2 reports the descriptive statistics for all the variables. The data show that the CSR_Index is, on average, 0.382 out of 1 , and therefore, the firms in our sample are moderately socially responsible. Furthermore, Table 2 also shows the representation of female institutional directors, pressure-sensitive female directors and pressure-resistant female directors on boards to be, on average, $4.13 \%, 1.02 \%$ and $3.11 \%$ respectively. In addition, boards comprise $31.91 \%$ independent directors on average and the mean for insider 
ownership is $8.72 \%$. Furthermore, firm size (the log of the total assets in thousands of Euros) is 13.25 , leverage is $52.34 \%$, board size is 10.77 members and ROA is $3.55 \%$, on average. Finally, the transport sector accounts for $3.34 \%$ of firms, cement, glass and construction materials $2.94 \%$, commerce and other services $10.61 \%$, construction $7.95 \%$, energy and water $7.76 \%$, the financial and insurance sector $2.85 \%$, the chemical industry $3.14 \%$, real estate $11.59 \%$, mass media $3.73 \%$, basic metal industries $4.32 \%$, other processing industries $2.41 \%$, metal processing industries $9.82 \%$ and other $7.76 \%$.

[Insert Table 2 about here]

\subsection{Univariate analysis}

In Table 3, we report the mean differences of the independent variables. For this analysis, we created two groups based on the median of the dependent variable. One group is composed of firms with a CSR_Index greater than the CSR_Index median for the whole group, and the other group is made up of firms with a CSR_Index lower than the CSR_Index median of the whole group.

\section{[Insert Table 3 about here]}

Table 3 shows that the mean difference between the variables WINST and WRESIST exhibit a positive sign, as predicted, and are statistically significant. Thus, these findings suggest that firms with a higher proportion of female institutional directors and female pressure-resistant directors on their boards are more likely to disclose CSR information than firms with a lower proportion of such directors. Contrary to our expectations, pressuresensitive female institutional directors (WSENSIT) exhibit a positive sign, but they are not statistically significant. Barako and Brown (2008) and Prado-Lorenzo and García-Sánchez (2010) also show the positive effect of board gender diversity on CSR reporting, in line with our results regarding female institutional and female pressure-resistant directors.

\subsection{Multivariate analysis}

Table 4 presents the correlation matrix testing for multicollinearity. As can be observed, all the coefficients are lower than 0'8. Therefore, according to these findings, multicollinearity is not a concern.

[Insert Table 4 about here] 
Table 5 shows the results for model 1, in which the effects of female institutional directors on the CSR_Index is analysed. As expected, the proportion of female institutional directors exhibits a positive sign, and is statistically significant. Thus, the first hypothesis cannot be rejected. Our results support the thesis that female institutional directors on boards are positively associated with CSR reporting, consistent with Bilimoria and Piderit (1994), Shrader et al. (1997), Williams (2003), Zelechowski and Bilimoria (2006) and Boulouta (2013). This result suggests that gender diversity on boards exerts a positive impact on CSR issues, because female directors are usually more engaged with social and environmental matters than men. Furthermore, our evidence also supports theories that argue that female directors are more transparent and more likely to encourage good practices (Barako and Brown, 2008; Prado-Lorenzo and García-Sánchez, 2010).

[Insert Table 5 about here]

Table 6 reports the findings for Models 2 and 3, in which we analyse how pressuresensitive female institutional directors and pressure-resistant female institutional directors, respectively, affect CSR reporting. Model 2 in Table 6 shows that the proportion of pressuresensitive female institutional directors presents, as expected, a negative sign, but it is insignificant. Hence, the second hypothesis is rejected. Contrary to our expectations, this finding suggests that pressure-sensitive female institutional directors do not affect CSR disclosure. In this regard, although gender diversity could positively affect CSR reporting, it may not be sufficient to alter the effect of the short-term perspective held by pressuresensitive institutional directors, which is a view supported by Johnson and Greening (1999).

Finally, model 3 in Table 6 reports the relationship between pressure-resistant institutional female directors and CSR disclosure. The variable representing pressure-resistant women directors, as predicted, presents a positive sign and is significant. Accordingly, the third hypothesis cannot be rejected. This finding suggests that pressure-resistant female institutional directors have a positive effect on CSR reporting (Bilimoria and Piderit, 1994; Shrader et al., 1997; Williams, 2003; Zelechowski and Bilimoria, 2006). This evidence is supported by authors such as Donaldson and Davis (1991), who argue that female directors on a board exert a positive impact on the company's stakeholders, as well as Luoma and Goodstein (1999), who show that female directors affect transparent and fair decisions in a positive way. Consequently, our findings reinforce the thesis that gender diversity, concretely pressure-resistant female institutional directors on boards, is good in terms of boosting CSR disclosure. 
[Insert Table 6 about here]

Concerning the control variables, board independence (BINDEP), return on assets (ROA), firm size (SIZE) and board size (BSIZE) are positive and statistically associated with CSR disclosure in all the models provided in Tables 5 and 6. The control variable insider ownership (INSOWN) shows a negative sign, according to our expectations, and is statistically significant. Finally, our results show those sectors that are more likely to disclose CSR information. In particular, commerce and other services (COMER), construction (CONST), energy and water (EW), the chemical industry (CHIN), mass media (MASSM), basic metal industries (BMI), other processing industries (OPI) and other sectors (OTHR) show a positive sign and are statistically significant. The cement, glass and construction materials (CGCM) sector presents a positive sign, but it is only significant for model 1 . Therefore, the aforementioned sectors positively affect CSR reporting, which is logical based on the high environmental and social impact that their activities exert. In contrast, the real estate (RE) sector is statistically and negatively associated with CSR matters, which implies that this sector is less likely to report information on CSR issues. The remaining variables lack significance.

We also address the issue of possible endogeneity between our independent variables (WINDEP, WSENSIT, WRESIST) and CSR disclosure. The direction of causality between the independent variables and CSR reporting is more likely to go from the directors analysed in the paper to CSR disclosure, although it is also likely that CSR disclosure may have an effect on board composition. This matter is addressed by running a two-stage least-squares (2SLS) model (Klock et al., 2005). For the sake of brevity, the findings are not shown, but they are in accord with the core results of our analysis.

\subsection{Sensitivity analysis}

We checked the robustness of our models using as the dependent variable the unweighted CSR_Index (our dependent variable without division by 3). The results, not provided for the sake of brevity, demonstrate that the proportion of female institutional directors (WINST) and pressure-resistant female institutional directors (WRESIST) exhibit a positive sign, as expected, and are statistically significant. Regarding pressure-sensitive female institutional directors (WSENSIT), the results are insignificant. Hence, this evidence corroborates our results, and accordingly, we can affirm that our findings do not depend on the measure of CSR reporting. 


\section{CONCLUSIONS}

Due to the importance of corporate governance, academic research has extensively analysed board composition in relation to firm value and CEO compensation, among other matters. Our paper tries to fill the gap in the prior literature concerning the role played by female institutional directors in a firm's decision to disclose CSR information. To deepen the analysis of female institutional directors and their impact on CSR policies, we also differentiate between female institutional directors with business ties to the company (pressure-sensitive female institutional directors) and directors who do not maintain such business links (pressure-resistant female institutional directors).

Our results show that female institutional directors on the whole have a positive impact on CSR disclosure. This finding supports the monitoring hypothesis, stressing the importance of reputation for female institutional directors, in line with their long-term perspective. Furthermore, our results also show that pressure-resistant female institutional directors exert a positive effect on CSR reporting due to their long-term perspective. Moreover, they encourage firms to behave in a responsible way. Contrary to our expectations, pressure-sensitive female institutional directors do not have any effect on CSR policy, suggesting that banks and insurance companies hold a short-term position and, thus, simply seek to enhance their own profit.

This study has various implications. First, this analysis offers a new framework for the role played by female institutional directors in CSR disclosure and, therefore, may help policymakers to promote CSR disclosure in the Spanish context, in which institutional directors account for almost $40 \%$ of board. Second, this paper provides new insights for NGOs, which may consider our evidence in helping companies to gain a better understanding of the importance played by female institutional directors in firms' decisions to disclose CSR information in their own and society's interests. Third, our results stress the positive effect of female institutional directors and pressure-resistant female directors on boards in relation to CSR disclosure; this evidence may be of importance for those companies wishing to promote CSR activities. Finally, this study may be helpful for policymakers as our findings provide evidence of the role played by certain types of female directors, hence potentially making it easier to take action to promote responsible behaviour among Spanish listed firms.

This paper also has a particular limitation. Focusing on theory and prior empirical evidence, we have controlled for many factors. However, it is likely that there may be unknown factors potentially affecting CSR policies and practices. 
Finally, we unlock a line of research with this study, namely that it may be interesting to analyse the role played by the directors analysed herein in relation to CSR policy concerning Spanish financial entities and small and medium-sized enterprises (SMEs).

\section{REFERENCES}

Abbott, W. F. and Monsen, J. R. (1979). On the measurement of corporate social responsibility. Academy of Management Journal, 22:501-515

Abd-Elsalam OH, El-Masry A (2008). The impact of board independence and ownership structure on the timeliness of corporate internet reporting of Irish-listed companies. Managerial Finance, 34:907-918.

Adams, C. A. (2002). Internal organisational factors influencing corporate social and ethical reporting: Beyond current theorising. Accounting, Auditing \& Accountability Journal, 15(2), 223-250.

Aguilera, R. V., Rupp, D. E., Williams, C. A. y Ganapathi, J. (2007). Putting the Sback in corporate social responsibility: A multilevel theory of social change in organizations. Academy of Management Review, 32(3), 836-863.

Ajinkya, B., Bhojraj, S., \& Sengupta, P. (2005). The association between outside directors, institutional investors and the properties of management earnings forecasts. Journal of Accounting Research, 43(3), 343-376.

Ali, A., Chen, T. Y., \& Radhakrishnan, S. (2007). Corporate disclosures by family firms. Journal of Accounting and Economics, 44(1), 238-286.

Almazan A, Hartzell JC, Starks LT (2005). Active institutional shareholders and costs of monitoring: Evidence from executive compensation. Financial Management 34:5-34.

Andrés, P., V. Azofra and F. López: 2005, 'Corporate Boards in OECD Countries: Size, Composition, Functioning and Effectiveness', Corporate Governance: An International Review 13(2), 197-210.

Aupperle, K. E., Carroll, A. B., \& Hatfield, J. D. (1985). An empirical examination of the relationship between corporate social responsibility and profitability. Academy of Management Journal, 28(2), 446-463.

Arellano, M. 2003. Panel data econometrics. Oxford: Oxford University Press.

Arjoon, S. (2008). Corporate governance: An ethical perspective. Journal of Business Ethics, 61, 343-352.

Aupperle, K. E., Carroll, A. B., \& Hatfield, J. D. (1985). An empirical examination of the relationship between corporate social responsibility and profitability. Academy of Management Journal, 28(2), 446-463.

Ayuso S., Argandoña A. (2007). Responsible corporate governance: Towards a stakeholder board of directors? Working Paper No. 701, IESE Business School,Barcelona, July.

Bakan, D. (1966). The duality of human existence: Isolation and communion in western man. Boston: Beacon Press.

Ballesteros, B. C., Rubio, R. G., \& Ferrero, J. M. (2015). Efecto de la composición del consejo de administración en las prácticas de responsabilidad social corporativa. Revista de Contabilidad, 18(1), 20-31.

Barako DG, Brown AM. 2008. Corporate social reporting and board representation: Evidence from the Kenyan banking sector. Journal of Management and Governance 12: 309324. 
Baums T, Buxbaum RM, Hopt KJ (1993). Institutional investors and corporate governance. Berlin.

Bies, R. J., Bartunek, J. M., Fort, T. L. y Zald, M. N. (2007). Corporations as social change agents: Individual, interpersonal, institutional, and environmental dynamics. Academy of Management Review, 32(3), 788-793.

Bilimoria, D., \& Piderit, S. K. (1994). Board committee membership: Effects of sex-based bias. Academy of Management Journal, 37, 1453-1477.

Bhattacharya P, Graham M (2007). Institutional ownership and firm performance: evidence from Finland. Australasian Meeting of the Econometric Society1-33.

Bhojraj S, Sengupta P (2003). Effect of corporate governance on bond ratings and yields: The role of institutional investors and outside directors. The Journal of Business 76:455475.

Black B (1992). Institutional Investors and corporate governance: The case for institutional voice. Journal of Applied Corporate Finance 5:19-32.

Boulouta, I. (2013). Hidden connections: The link between board gender diversity and corporate social performance. Journal of Business Ethics, 113(2), 185-197.

Borokhovich K, Brunarski K, Harman Y, Parrino R (2006). Variation in the monitoring incentives of outside stockholders. Journal of Law and Economics 49:651-680.

Brickley, J., R. Lease, and C. Smith, (1988). Ownership Structure and Voting on Antitakeover Amendments, Journal of Financial Economics 20, 267-292.

Byrnes, J., Miller, D. \& Schafer, W. 1999. Gender Differences in Risk Taking: A Metaanalysis. Psychological Bulletin, 125(3): 367-383.

Campbell, K., \& Mínguez-Vera, A. (2008). Gender diversity in the boardroom and firm financial performance. Journal of Business Ethics, 83(3), 435-451.

Brickley J, Lease RC, Smith CW (1988). Ownership structure and voting on antitakeover amendments. Journal of Financial Economics 20:267-291.

Carroll, A. B. (1979). A three-dimensional conceptual model of corporate performance. Academy of Management Review, 4(4), 497-505.

Carroll, A. (1996). Business and Society. Ethics and Stakeholders Management (Southern Western College Publishing, Cincinnati, $\mathrm{OH})$.

Carter, D.A., B.J. Simkins, and W.G. Simpson, (2003). Corporate Governance, Board Diversity, and Firm Value, Financial Review 38, 1, pp. 33-53.

Catalyst. (1995). The CEO View: Women on Corporate Boards. New York: Catalyst.

Charitou A, Louca C, Panayides S (2007). Cross-Listing, bonding hypothesis and corporate governance. Journal of Business Finance \& Accounting 34:1281-306.

Chung R, Firth M, Kim JB (2002). Institutional monitoring and opportunistic earnings management. Journal of Corporate Finance 8:29-48.

Colpan AM, Yoshikawa T (2012). Performance Sensitivity of Executive Pay: The Role of Foreign Investors and Affiliated Directors in Japan. Corporate Governance (Oxford) 20:547-561.

Correa, M. E., Flynn, S., \& Amit, A. (2004). Responsabilidad social corporativa en América Latina: una visión empresarial (Vol. 85). United Nations Publications.

Cotter, J., \& Najah, M. M. (2012). Institutional investor influence on global climate change disclosure practices. Australian journal of management, 0312896211423945.

Cox, P., Brammer, S., \& Millington, A. (2004). An empirical examination of institutional investor preferences for corporate social performance. Journal of Business Ethics, 52(1), 27-43.

Crespí R, García-Cestona M and Salas V (2004). Governance mechanisms in Spanish banks. Does ownership matter?.Journal of Banking and Finance 28:2311-2330. 
David, P., Hitt, M. A., \& Gimeno, J. (2001). The influence of activism by institutional investors on R\&D. Academy of management Journal, 44(1), 144-157.

David, P., Kochhar, R., \& Levitas, E. (1998). The effect of institutional investors on the level and mix of CEO compensation. Academy of Management Journal, 41(2), 200-208.

Deegan, C., \& Gordon, B. (1996). A study of the environmental disclosure practices of Australian corporations. Accounting and business research, 26(3), 187-199.

De Villiers C, Naiker V, Van Staden CJ (2011) The effect of board characteristics on firm environmental performance. J Manag 37:1636-1663

Domench, P. A. (2003). La divulgación de la información social y medioambiental de la gran empresa española en el período 1994-1998: Situación actual y perspectivas. Spanish Journal of Finance and Accounting/Revista Española de Financiación y Contabilidad, 32(117), 571-601.

Donaldson, L., \& Davis, J. H. (1991). Stewardship theory or agency theory: CEO governance and shareholder returns. Australian Journal of Management, 16(1), 49-64.

Dong M, Ozkan A (2008). Institutional investors and director pay: An empirical study of UK companies. Journal of Multinational Financial Management 18:16-29.

Eagly, A. (1987). Sex differences in social behaviour: A social role interpretation. Hillsdale: Erlbaum

Eagly, A. H., Johannesen-Schmidt, M. C. y Van Engen, M. L. (2003). Transformational, transactional, and laissez-faire leadership styles: A meta-analysis comparing women and men. Psychological Bulletin, 129, 569-591.

Eng, L. L. (1999). Comparing changes in stockholdings of different institutional investors. Journal of Investing, 1, 46-50.

Ferreira M, Matos P (2008). The colors of investors' money: The role of institutional investors around the world. Journal of Financial Economics 88:499-533.

Finkelstein, S. 1992. Power in top management teams: Dimensions, measurement, and validation. Academy of Management Journal, 35: 505-538. Fortune. 1993. What activist investors want. March 8: 59-63.

Finseth, E. J. (2011). Shareholder Activism by Public Pension Funds and the Rights of Dissenting Employees Under the First Amendment. Harv. JL \& Pub. Pol'y, 34, 289.

Freeman, R.E. 1984. Strategic Management. A Stakeholder Approach. Marshfield, MA: Pitman.

García-Ayuso, M., \& Larrinaga, C. (2003). Environmental disclosure in Spain: Corporate characteristics and media exposure. Spanish Journal of Finance and Accounting/Revista Española de Financiación y Contabilidad, 32(115), 184-214.

García-Meca, E., \& Pucheta-Martínez, M.C., (2015). Do institutional, independent and foreigners influence value creation when they are board members? Working paper, Technical University of Cartagena and University and Jaume I of Castellón, Spain.

Gillan S, Starks L (2000). Corporate governance proposals and shareholder activism: The role of institutional investors. Journal of Financial Economics 57:275-305.

Goodstein, J., Gautam, K., \& Boeker, W. (1994). The effects of board size and diversity on strategic change. Strategic management journal, 15(3), 241-250.

Gorton, G., \& Schmid, F. (2000). Class struggle inside the firm: a study of German codetermination (No. w7945). National Bureau of Economic Research.

Graves, S. B., \& Waddock, S. A. 1994. Institutional owners and corporate social performance. Academy of Management Journal, 37: 1034-1046.

Green Paper Book: Promoting a European framework for Corporate Social Responsibility (2001). Brussels, 18 July 2001. Doc/01/9. European Commission.

Green Paper Book: The EU corporate governance framework (2011). Brussels, 5.4.2011 $\operatorname{COM}(2011) 164$ final. European Commission 
Harjoto, M. A. y Jo, H. (2011). Corporate governance and CSR nexus. Journal of BusinessEthics, 100, 45-67.

Harrigan, K. R. (1981). Numbers and positions of women elected to corporate boards. Academy of Management Journal, 24, 619-625.

Heidrick, Struggles, 2011. Challenging board performance. European Report on corporate governance: Heidrick \& Struggles.

Hill, C. W., \& Snell, S. A. (1988). External control, corporate strategy, and firm performance in research-intensive industries. Strategic Management Journal, 9(6), 577-590.

Husted, B. W., \& Allen, D. B. (2011). Corporate social strategy.

Ibrahim, N. A. y Angelidis, J. P. (1995). The corporate social responsiveness orientation of board members: Are there differences between inside and outside directors? Journal of Business Ethics, 14(5), 405-410.

Jensen MC, Meckling WH (1976). Theory of the firm: Managerial behavior, agency costs and ownership structure. Journal of Financial Economics 3:305-360.

Jenkins, H. (2006). Small business champions for corporate social responsibility. Journal of Business Ethics, 67(3), 241-256.

Jianakoplos, N. \& Bernasek, A. 1998. Are Women More Risk Averse? Economic Inquiry, 36(4): 620-630.

Johnson, R. A. y Greening, D. W. (1999). The effects of corporate governance and institutional ownership types on corporate social performance. Academy of Management Journal, 42(5), 564-576.

Kassinis G, Vafeas M (2002) Boards and outside stakeholders as determinants of environmental litigation. Strateg Manag J 23:399-415

Kesner, I. F. (1988). Directors' characteristics and committee membership: An investigation of type, occupation, tenure, and gender. Academy of Management Journal, 31, 66-84.

Khazanchi, D. 1995. Unethical behavior in information systems: The gender factor. Journal of Business Ethics, 14(9): 741-749.

Kim, Y., Park, M. S. y Wier, B. (2012). Is earnings quality associated with corporatesocial responsibility? The Accounting Review, 87(3), 761-796.

Kolk, A., \& Pinkse, J. (2007). Towards strategic stakeholder management? Integrating perspectives on corporate responses to climate change. Integrating Perspectives on Corporate Responses to Climate Change. Corporate Governance: The International Journal of Business in Society, 7(4), 370-378.

Klock, M.S., Mansi, S.A., Maxwell, W.F., 2005. Does corporate governance matter to bondholders?, Journal of Financial and Quantitative Analysis, 40 (4), 693-719.

Krüger, P. (2009). Corporate social responsibility and the board of directors. Job Market Paper. Toulouse School of Economics, France.

Lee, M. D. P. (2011). Configuration of external influences: The combined effects of institutions and stakeholders on corporate social responsibility strategies. Journal of Business Ethics, 102(2), 281-298.

Lee, J. H., \& Roberts, M. J. (2015). International returnees as outside directors: A catalyst for strategic adaptation under institutional pressure. International Business Review, 24(4), 594-604.

La Porta, R., Lopez-de-Silane, F., Shleifer, A. y Vishny, R. W. (2000). Investor protectionand corporate governance. Journal of Financial Economics, 58, 3-27.

Liao, L., Luo, L., \& Tang, Q. (2015). Gender diversity, board independence, environmental committee and greenhouse gas disclosure. The British Accounting Review, 47(4), 409424. 
Ljungqvist A, Marston F, Starks LT, Wei KD, Yan H (2007). Conflicts of interest in sell-side research and the moderating role of institutional investors. Journal of Financial Economics 85:420-456.

López-Iturriaga, F. J., García-Meca, E. \& Tejerina Gaite, F. 2015. Institutional directors and board compensation: Spanish evidence. Business Research Quarterly, 18, 161-173.

Luoma, P., \& Goodstein, J. (1999). Stakeholders and corporate boards: Institutional influences on board composition. Academy of Management Journal, 42, 553-563.

Manzaneque, M., Merino, E. \& Priego, A.M. 2016. The role of institutional shareholders as owners and directors and the financial distress likelihood. Evidence from a concentrated ownership context. European Management Journal, Forthcoming.

Mahapatra, S. 1984. Investor reaction to corporate social accounting. Journal of Business Finance and Accounting, 11: 29-40.

Maignan, I., Ferrell, O. C., \& Hult, G. T. (1999). Corporate citizenship: Cultural antecedents and business benefits. Journal of the Academy of Marketing Science, 27(4), 455-469.

Matten, D. y Moon, J. (2008). 'Implicit' and 'explicit' CSR: A conceptual frameworkfor a comparative understanding of corporate social responsibility. The Academy of Management Review, 33(2), 404-424.

Matsumura, E. A., \& Shin, J. Y. (2005). Corporate governance reform and CEO compensation: intended and unintended consequences. Journal of Business Ethics, 62(2), 101-113.

Mateos de Cabo, R. M., Gimeno, R. \& Escot, L. 2010. Discriminación en consejos de administración: Análisis e implicaciones económicas. Revista de Economía Aplicada, 18(53): 131-162.

Miras-Rodríguez, M., Carrasco-Gallego, A. y Escobar-Pérez, B. (2013). Are sociallyresponsible behaviors paid off equally? A cross-cultural analysis. Corporate SocialResponsibility and Environmental Management.

Moneva J.M and Llena, F. (1996). Análisis de la información sobre responsabilidad social en las empresas industriales que cotizan en bolsa. RevistaRevista Española de Financiación y Contabilidad. XXV (no87): 361-401.

Montiel, I., \& Delgado-Ceballos, J. (2014). Defining and measuring corporate sustainability are we there yet?. Organization \& Environment, 27(2), 113-139.

Morsing, M., \& Schultz, M. (2006). Corporate social responsibility communication: stakeholder information, response and involvement strategies. Business Ethics: A European Review, 15(4), 323-338.

Neubaum, D. O., \& Zahra, S. A. (2006). Institutional ownership and corporate social performance: The moderating effects of investment horizon, activism, and coordination. Journal of Management, 32(1), 108-131.

Nieto Antolín, M. and Fernández Gago, R., (2004). Responsabilidad social corporativa: la última innovación en management. Universia Bussiness Review 1: 28-39. Available at: http://www.redalyc.org/articulo.oa?id=43300103

O'Connor, T. (2013), 'Dividend payout and corporate governance in emerging markets: which governance provisions matter?' Department of Economics, Finance and Accounting, National University of Ireland-Maynooth, 1-30.

Peloza, J., \& Shang, J. (2011). How can corporate social responsibility activities create value for stakeholders? A systematic review. Journal of the Academy of Marketing Science, 39, 117-135.

Perez-Batres, L. A., Doh, J. P., Miller, V. V., \& Pisani, M. J. (2012). Stakeholder pressures as determinants of CSR strategic choice: Why do firms choose symbolic versus substantive self-regulatory codes of conduct?. Journal of Business Ethics, 110(2), 157172. 
Pfeffer, J. (1972). Size and composition of corporate boards of directors: The organization and its environment. Administrative science quarterly, 218-228.

Prado-Lorenzo JM, García-Sánchez IM. 2010. The role of the board of directors in disseminating relevant information on greenhouse gases. Journal of Business Ethics 97: 391-424.

Pucheta-Martínez, M. C. \& García-Meca, E. 2014. Institutional Investors on Boards and Audit Committees and Their Effects on Financial Reporting Quality. Corporate Governance: An International Review, 22(4): 347-363.

Pucheta-Martínez, M.C. and López-Zamora, B. (2015). How do female, institutional and foreign directors influence dividend policies?

Ramalingegowda S, Yu Y (2012). Institutional ownership and conservatism. Journal of Accounting and Economics 53:98-114.

Rashid, A. (2013). CEO duality and agency cost: evidence from Bangladesh. Journal of Management \& Governance, 17: 989-1008.

Ricart, J.E., M.A.Rodríguez, and P. Sánchez, (2005), "Sustainability in the Boardroom: An Empirical Examination of Dow Jones Sustainability World Index Leaders," Corporate Governance: The International Journal of Effective Board Performance, 5, 3, pp. 2441.

Sarkis, J., Gonzalez-Torre, P., \& Adenso-Diaz, B. (2010). Stakeholder pressure and the adoption of environmental practices: The mediating effect of training. Journal of Operations Management, 28(2), 163-176.

Sánchez-Ballesta, J. P. y García-Meca, E. (2007). A meta-analytic vision of the effect of ownership structure on firm performance. Corporate Governance: An International Review, 15(5), 879-892.

Sánchez-Ballesta, J. P. and García-Meca, E., (2005). Audit qualifications and corporate governance in Spanish listed firms. Managerial Auditing Journal 20:725-738.

Santos, C. M. (2011). La Responsabilidad Social Corporativa como criterio de gestión empresarial. Lan Harremanak. Revista de Relaciones Laborales, (14).

Seoane, J. R. Q. (2006). Las cajas de ahorros en el ámbito de la responsabilidad social corporativa. Documentos de Trabajo (Fundación Carolina), (7), 61-84.

Sethi, S. P. (2005). Investing in socially responsible companies is a must for public pension funds-because there is no better alternative. Journal of Business Ethics, 56(2), 99-129.

Shrader, C. B., Blackburn, V. B., \& Iles, P. (1997). Women in management and firm financial performance: An exploratory study. Journal of Managerial Issues, 9(3), 355-373.

Siebens, H. (2002). Concepts and working instruments for corporate governance. Journal of Business Ethics, 39(1-2), 109-116.

Starks, L. T. 1987. Performance incentive fees: An agency

Van der Walt, N. and Ingley, C. (2003). Board dynamic and the influence of professionalbackground, gender and ethnic diversity of directors. Corporate Governance: AnInternational Review, 11(3), 218-234.

Waddock, S. (2003). Stakeholder performance implications of corporate responsibility. International Journal of Business Performance Management, 5(2), 114-124.

Waddock, S and Graves, S. (1997). The corporate social performance-financial performance link. Strategic Management Journal, 18:303-319.

Wan-Hussin WN (2009). The impact of family-firm structure and board composition on corporate transparency: Evidence based on segment disclosures in Malaysia. International Journal of Accounting 44:313-333.

Wan-Hussin, W. N. (2009). The impact of family-firm structure and board composition on corporate transparency: evidence based on segment disclosures in Malaysia. International Journal of Accounting, 44, 313-333. 
Webb, E. (2004). An examination of socially responsible firms' board structure. Journal of Management and Governance, 8(3), 255-277.

Wen, S. (2009). Institutional investor activism on socially responsible investment: effects and expectations. Business Ethics: A European Review, 18(3), 308-333.

Williams, R. J. (2003). Women on corporate boards of directors and their influence on corporate philanthropy. Journal of Business Ethics, 42, 1-10.

Xiangqian L (2002). Institutional investors and corporate governance. Productivity Research, 3.

Xie B, Davidson N, Dadalt J (2003). Eamings management and corporate govemance: The role of the board and the audit committee. Journal of Corporate Finance 9:295-316.

Yamahaki, C. (2013). Shareholder engagement in emerging markets: institutional and organisational determinants in Brazil and South Africa (Doctoral dissertation, Middlesex University).

Zahra, S. A., Oviatt, B. M. and Minyard, K. (1993). Effects of corporate ownership and board structure on corporate social responsibility and financial performance. Academy of Management Proceedings, 336-340.

Zahra, S. A. and Stanton, W. W. (1988). The implications of board of directors'composition on corporate strategy and performance. International Journal ofManagement, 5(2), 229-236.

Zahra, S.A., Neubaum, D. \& Huse, M. 2000. Entrepreneurship in medium-sized companies: Exploring the effects ownership and governance systems. Journal of Management.

Zattoni, A. (2011). Who should control a corporation? Toward a contingency stakeholder model for allocating ownership rights. Journal of Business Ethics, 103(2), 255-274.

Zelechowski, S. A., \& Bilimoria, D. (2006). Characteristics of CEOs and boards with women inside directors. Corporate Board: Roles, Duties and Composition, 2(2), 14-21.

Table 1

Variable description

\begin{tabular}{ll}
\hline Variables & Description \\
\hline WINST & $\begin{array}{l}\text { Ratio between the total number of female institutional directors on board and the total number of } \\
\text { directors on board }\end{array}$ \\
Ratio between the total number of pressure-resistant female institutional directors on board and the \\
total number of directors on board
\end{tabular}


ROA Ratio between earnings before interest and taxation (EBIT) and total book assets

SIZE Logarithm of the total assets

BSIZE Total number of directors on boards

INSOWN Percentage of shares held by insiders (directors)

TR Transport sector

CGCM Cement, glass and construction materials sector

COMER Commerce and other services sector

CONST Construction sector

EW Energy and water sector

FININS Financial and insurance sector

CHIN Chemical industry sector

RE Real estate sector

MASSM Mass media sector

BMI Basic metal industries sector

OPI Other processing industries

MPI Metal processing industries sector

OTHR Agriculture and fisheries and new technologies sector

Table 2

Main Descriptive Statistics

\begin{tabular}{lcccccc}
\hline \multicolumn{1}{l}{ Panel A. Continuous variables } & & & & & \\
\hline \multicolumn{1}{c}{ Variables } & $\mathbf{N}$ & Mean & Std. Dev. & Perc. 25 $^{\text {th }}$ & Perc. 50 $^{\text {th }}$ & Perc. 75 $^{\text {th }}$ \\
\hline CSR_Index & 1018 & 0.382 & 0.439 & 0.000 & 0.000 & 0.833 \\
WINST & 1018 & 4.136 & 8.106 & 0.000 & 0.000 & 6.250 \\
WSENSIT & 1018 & 1.024 & 2.594 & 0.000 & 0.000 & 0.000 \\
WRESIST & 1018 & 3.112 & 6.330 & 0.000 & 0.000 & 5.000
\end{tabular}




\begin{tabular}{lcccccc} 
INDEP & 1018 & 31.913 & 17.984 & 21.000 & 30.884 & 42.857 \\
LEV & 1018 & 52.344 & 23.583 & 34.352 & 54.852 & 70.150 \\
ROA & 1018 & 3.550 & 14.820 & -0.834 & 3.227 & 8.343 \\
SIZE & 1018 & 13.249 & 1.803 & 11.897 & 13.089 & 14.476 \\
BSIZE & 1018 & 10.767 & 3.801 & 8.000 & 10.000 & 13.000 \\
INSOWN & 1018 & 8.719 & 17.274 & 0.000 & 0.103 & 8.452 \\
\hline
\end{tabular}

\begin{tabular}{lcccc}
\hline Panel B. Dummies variables & \multicolumn{3}{c}{} \\
\hline & $\mathbf{0}$ & $\mathbf{0 \%}$ & $\mathbf{1}$ & $\mathbf{1 \%}$ \\
\hline TR & 984 & $96.66 \%$ & 34 & $3.34 \%$ \\
CGCM & 988 & $97.05 \%$ & 30 & $2.94 \%$ \\
COMER & 910 & $89.39 \%$ & 108 & $10.61 \%$ \\
CONST & 937 & $92.04 \%$ & 81 & $7.95 \%$ \\
EW & 939 & $92.24 \%$ & 79 & $7.76 \%$ \\
FININS & 989 & $97.15 \%$ & 29 & $2.85 \%$ \\
CHIN & 986 & $96.86 \%$ & 32 & $3.14 \%$ \\
RE & 900 & $88.41 \%$ & 118 & $11.59 \%$ \\
MASSM & 980 & $96.27 \%$ & 38 & $3.73 \%$ \\
BMI & 974 & $95.68 \%$ & 44 & $4.32 \%$ \\
OPI & 993 & $97.59 \%$ & 24 & $24,06 \%$ \\
MPI & 918 & $90.18 \%$ & 100 & $9.82 \%$ \\
OTHR & 939 & $92.24 \%$ & 79 & $7.76 \%$ \\
\hline
\end{tabular}

Mean, standard deviation and percentiles $25^{\text {th }}, 50^{\text {th }}$ and $75^{\text {th }}$. Panel A and B show the continuous and dummy variables, respectively. CSR_Index is the dependent variable, measured as the sum of the score of the three areas analysed divided by 3; WINST is the proportion of institutional female directors on board; WSENSIT is the proportion of pressure-sensitive institutional female directors (i.e., banks and insurance companies); WRESIST is the proportion of pressure-resistant institutional female directors (i.e., investment funds); INDEP is the proportion of independent directors on the board; BDSIZE is the number of directors on boards; LEV is the debt over total assets; ROA is the operate income before interests and taxes over total assets; SIZE is the log of total assets; BSIZE is the number of member on boards; INSOWN is the Percentage of shares held by insiders (directors) on board; TR is dummy that takes the value 1 if the firm belongs to a transport sector and 0 , otherwise; CGCM is dummy that takes the value 1 if the firms belong to a cement, glass and construction materials sector and 0, otherwise; COMER is dummy that takes the value 1 if the firm belongs to a commerce and other services sector and 0 , otherwise; CONST is dummy that takes the value 1 if the firm belongs to a construction sector and 0 , otherwise; EW is dummy that takes the value 1 if the firm belongs to an energy and water sector and 0, otherwise; FININS is dummy that takes the value 1 if the firm belongs to a financial and insurance sector and 0, otherwise; CHIN is dummy that takes the value 1 if the firm belongs to a chemical industry sector and 0 , otherwise; RE is dummy that takes the value 1 if the firm belongs to a real estate sector and 0 , otherwise; MASSM is dummy that takes the value 1 if the firm belongs to a mass media sector and 0 , otherwise; BMI is dummy that takes the value 1 if the firm belongs to a basic metal industries sector and 0 , otherwise; OPI is dummy that takes the value 1 if the firm belongs to another processing industries and 0 , otherwise; MPI is dummy that takes the value 1 if the firm belongs to a metal processing industries sector and 0 , otherwise and OTHR is dummy that takes the value 1 if the firm belong to other sectors and 0 , otherwise.

Table 3

Means comparison Test CSR_Index

\begin{tabular}{lcccc}
\hline Variables & $\begin{array}{c}\text { CSR_Index } \\
(>=\text { median }) \\
\text { Mean }\end{array}$ & $\begin{array}{c}\text { CSR_Index } \\
(<\text { median }) \\
\text { Mean }\end{array}$ & Mean & difference \\
\hline WINST & 4.528 & 3.798 & 0.730 & 0.076 \\
WSENSIT & 1.117 & 0.945 & 0.172 & 0.146 \\
WRESIST & 3.411 & 2.853 & 0.558 & 0.080 \\
\hline
\end{tabular}


CSR_Index is the dependent variable, measured as the sum of the score of the three areas analysed divided by 3; WINST is the proportion of institutional female directors on board; WSENSIT is the proportion of pressure-sensitive institutional female directors (i.e., banks and insurance companies); WRESIST is the proportion of pressure-resistant institutional female directors (i.e., investment funds). 
Table 4

\section{Correlation Matrix}

\begin{tabular}{|c|c|c|c|c|c|c|c|c|c|c|c|c|c|c|c|c|c|c|c|c|c|c|}
\hline & CSR_Index & $x$ WINST & WSENSIT & TWRESIST & T BINDEP & LEV & ROA & SIZE & BSIZE & INSOWN & TR & CGCM & COMER CONSTR & EW & FININS & CHIN & $\mathrm{RE}$ & MASSM & BMI & OPI & MPI & OTHR \\
\hline CSR_Index & 1 & & & & & & & & & & & & & & & & & & & & & \\
\hline WINST & 0.040 & 1 & & & & & & & & & & & & & & & & & & & & \\
\hline WSENSIT & -0.012 & $0.158 * * *$ & 1 & & & & & & & & & & & & & & & & & & & \\
\hline WRESIST & 0.044 & $0.987 * * *$ & 0.027 & 1 & & & & & & & & & & & & & & & & & & \\
\hline BINDEP & $0.228 * * *$ & $-0.244 * * *$ & $*-0.083^{* * * *}$ & $*-0.234 * * *$ & * 1 & & & & & & & & & & & & & & & & & \\
\hline LEV & $0.102 * * *$ & $0.109 * * *$ & $0.054 * *$ & $0.098^{* * *}$ & $-0.170 * * *$ & 1 & & & & & & & & & & & & & & & & \\
\hline ROA & $0.118 * * *$ & $-0.139 * * *$ & $*-0.079 * *$ & $-0.128 * * *$ & * 0.015 & $-0.230 * * *$ & 1 & & & & & & & & & & & & & & & \\
\hline SIZE & $0.602 * * *$ & -0.012 & -0.013 & -0.008 & $0.102 * * *$ & $0.315^{* * * *}$ & $0.088 * *$ & 1 & & & & & & & & & & & & & & \\
\hline BSIZE & $0.388^{* * * *}$ & $0.055^{*}$ & -0.027 & $0.065^{* *}$ & -0.030 & $0.128^{* * * *}$ & $0.094 * * *$ & $0.619^{* * * *}$ & 1 & & & & & & & & & & & & & \\
\hline INSOWN & $-0.229 * * *$ & $0.064 * *$ & $-0.097 * * *$ & $0.078 * *$ & 0.002 & -0.018 & 0.007 & $-0.208 * * * \ldots$ & $-0.179 * * *$ & 1 & & & & & & & & & & & & \\
\hline $\mathrm{TR}$ & $0.130^{* * *}$ & -0.030 & 0.050 & -0.031 & 0.032 & $0.102^{* * *}$ & 0.003 & $0.213^{* * *}$ & $0.185^{* * * *}$ & $*-0.059 *$ & 1 & & & & & & & & & & & \\
\hline CGCM & 0.015 & 0.045 & -0.014 & 0.047 & -0.040 & 0.014 & 0.047 & $0.056^{*}$ & $0.067 * *$ & $*-0.149 * * *$ & * -0.032 & 1 & & & & & & & & & & \\
\hline COMER & -0.034 & 0.027 & -0.028 & $0.031^{* * *}$ & $0.081^{* * * *}$ & 0.013 & $-0.092^{* * * *}$ & $*-0.159 * * *$ & $-0.128^{* * * *}$ & $* * 0.206^{* * * *}$ & $-0.064 * *$ & $-0.060^{*}$ & 1 & & & & & & & & & \\
\hline CONSTR & $0.227 * * *$ & $0.135 * * *$ & $0.019 * * *$ & 0.132 & -0.015 & $0.145^{* * *}$ & -0.010 & $0.250 * * *$ & $0.154 * * *$ & $* \quad-0.021$ & $-0.054 * *$ & -0.051 & $-0.101 * * * \quad 1$ & & & & & & & & & \\
\hline EW & $0.292 * * *$ & $-0.134 * * *$ & $*-0.024 * * *$ & * $-0.132 * * *$ & $* 0.169 * * *$ & -0.049 & $0.108 * * *$ & $0.345 * * *$ & $0.272^{* * * *}$ & $*-0.188 * * * *$ & $*-0.053 * *$ & -0.050 & $-0.099 * * *-0.085 * * *$ & 1 & & & & & & & & \\
\hline FININS & -0.032 & -0.046 & -0.014 & $-0.045^{* *}$ & $-0.095 * * *$ & $-0.181 * * *$ & * $0.162 * * * *$ & 0.050 & $0.158 * * * *$ & $* \quad-0.013$ & -0.031 & -0.029 & $-0.059 * \quad-0.050$ & -0.049 & 1 & & & & & & & \\
\hline CHIN & -0.012 & $-0.066^{* *}$ & $-0.015^{* *}$ & $-0.064^{* * *}$ & $0.097 * * *$ & $-0.060^{*}$ & 0.035 & $-0.062^{* * *}$ & $-0.156^{* * *}$ & ** $0.073 * *$ & -0.033 & -0.031 & $-0.062^{* *} \quad-0.053^{*}$ & $-0.052^{*}$ & -0.038 & 1 & & & & & & \\
\hline $\mathrm{RE}$ & $-0.285^{* * * *}$ & * $\quad-0.016$ & 0.081 & $-0.037^{* * * *}$ & $*-0.118^{* * *}$ & $0.083^{* *}$ & $-0.218^{* * * *}$ & * $-0.071 * *$ & $-0.132^{* * * *}$ & *** $\quad-0.019$ & $-0.067^{* *}$ & $-0.063^{* *}$ & $-0.124 * * *-0.106 * * *$ & $-0.105^{* * * *}$ & $*-0.062 * *$ & $-0.065^{* *}$ & * 1 & & & & & \\
\hline MASSM & $0.139 * * *$ & $0.062 * *$ & $-0.016 * *$ & 0.065 & -0.046 & $0.053 *$ & 0.050 & $0.119 * * *$ & $0.167 * * * *$ & $*-0.106 * * *$ & $*-0.036$ & -0.034 & $-0.067 * * \quad-0.057 *$ & $-0.057 *$ & -0.033 & -0.035 & $-0.071^{*}$ & 1 & & & & \\
\hline BMI & -0.013 & $0.111 * * *$ & $-0.017 * * *$ & * $0.115 * * *$ & * $-0.180^{* * * *}$ & 0.044 & 0.018 & $-0.059 *$ & 0.049 & -0.012 & -0.039 & -0.037 & $-0.073^{* *}-0.062 * *$ & $-0.061 * *$ & -0.036 & -0.038 & $-0.077 * *$ & -0.041 & 1 & & & \\
\hline OPI & $-0.081 * * * *$ & * $\quad-0.046$ & -0.019 & -0.041 & -0.028 & $-0.213 * * *$ & * $0.079 * *$ & $-0.208 * * * \ldots$ & $-0.223 * * *$ & $* 0.131 * * *$ & $-0.104 * * *$ & * $-0.098 * * *$ & $*-0.193 * * *-0.165 * * *$ & $-0.163^{* * * *}$ & $*-0.096 * * *$ & $-0.101 * * *$ & $*-0.203 * * *$ & $*-0.110^{* * * *}$ & $-0.1197 * * *$ & 1 & & \\
\hline MPI & $-0.126^{* * * *}$ & * $\quad-0.019$ & -0.027 & -0.016 & 0.006 & $0.124 * * *$ & 0.039 & $-0.107^{* * * *}$ & $-0.061 *$ & * $\quad-0.023$ & $-0.061^{*}$ & $-0.057^{*}$ & $-0.113^{* * *}-0.097 * * *$ & $-0.095^{* * * *}$ & $*-0.056^{*}$ & $-0.059^{*}$ & $-0.119^{* * *}$ & $*-0.065^{* *}$ & $-0.0701 * *$ & $-0.185^{* * *}$ & 1 & \\
\hline OTHR & -0.024 & 0.018 & 0.020 & $0.021^{1 * * *}$ & $0.104 * * * *$ & -0.001 & $-0.110^{* * * *}$ & $*-0.081^{* * * * *}$ & -0.013 & -0.010 & $-0.053^{*}$ & -0.050 & $-0.099^{* * * *}-0.085^{* * * *}$ & $-0.084^{* * * * *}$ & $* \quad-0.049$ & $-0.052^{*}$ & $-0.105^{* * * *}$ & $-0.057 *$ & $-0.0616^{* * *}$ & $-0.163 * * *-0$ & $0.095 * * *$ & 1 \\
\hline
\end{tabular}


Table 5

Results of the Tobit regression for institutional female directors sit on boards

\begin{tabular}{|c|c|c|}
\hline Variables & Expected Sign & $\begin{array}{c}\text { Model } 1 \\
\text { Estimated coefficient } \\
\text { (p.value) }\end{array}$ \\
\hline WINST & + & $\begin{array}{c}0.023 * * * \\
(0.001)\end{array}$ \\
\hline BINDEP & + & $\begin{array}{c}0.016^{* * * *} \\
(0.000)\end{array}$ \\
\hline LEV & + & $\begin{array}{c}0.001 \\
(0.437)\end{array}$ \\
\hline $\mathrm{ROA}$ & + & $\begin{array}{c}0.007 * * \\
(0.017)\end{array}$ \\
\hline SIZE & + & $\begin{array}{l}0.470 * * * \\
(0.000)\end{array}$ \\
\hline BSIZE & + & $\begin{array}{c}0.030 * * \\
(0.045)\end{array}$ \\
\hline INSOWN & - & $\begin{array}{c}-0.010 * * * \\
(0.000)\end{array}$ \\
\hline CGCM & $+/-$ & $\begin{array}{c}0.375 \\
(0.218)\end{array}$ \\
\hline COMER & $+/-$ & $\begin{array}{c}0.774 * * * \\
(0.004)\end{array}$ \\
\hline CONST & $+/-$ & $\begin{array}{c}0.854 * * * \\
(0.001)\end{array}$ \\
\hline EW & $+/-$ & $\begin{array}{c}0.742 * * * \\
(0.005)\end{array}$ \\
\hline FININS & $+/-$ & $\begin{array}{l}-0.039 \\
(0.906)\end{array}$ \\
\hline CHIN & $+/-$ & $\begin{array}{c}0.755^{* *} \\
(0.017)\end{array}$ \\
\hline RE & $+/-$ & $\begin{array}{c}-1.313^{* * *} \\
(0.000)\end{array}$ \\
\hline MASSM & $+/-$ & $\begin{array}{c}0.891 * * * \\
(0.002)\end{array}$ \\
\hline BMI & $+/-$ & $\begin{array}{c}0.756 * * * \\
(0.009)\end{array}$ \\
\hline OPI & $+/-$ & $\begin{array}{c}0.693 * * * \\
(0.005)\end{array}$ \\
\hline MPI & $+/-$ & $\begin{array}{c}0.244 \\
(0.344)\end{array}$ \\
\hline OTHR & $+/-$ & $\begin{array}{r}0.610 * * \\
(0.022) \\
\end{array}$ \\
\hline $\mathrm{F}$ & & $690.38 * * *$ \\
\hline $\mathrm{R} 2$ & & $33.30 \%$ \\
\hline
\end{tabular}

CSR_Index is the dependent variable, measured as the sum of the score of the three areas analysed divided by 3; WINST is the proportion of institutional female directors on board; BDSIZE is the number of directors on boards; LEV is the debt over total assets; ROA is the operate income before interests and taxes over total assets; SIZE is the log of total assets; BSIZE is the number of member on boards; INSOWN is the Percentage of shares held by insiders (directors) on board; TR is dummy that takes the value 1 if the firm belongs to a transport sector and 0, otherwise; CGCM is dummy that takes the value 1 if the firms belong to a cement, glass and construction materials sector and 0, otherwise; COMER is dummy that takes the value 1 if the firm belongs to a commerce and other services sector and 0 , otherwise; CONST is dummy that takes the value 1 if the firm belongs to a construction sector and 0, otherwise; EW is dummy that takes the value 1 if the firm belongs to an energy and water sector and 0 , otherwise; FININS is dummy that takes the value 1 if the firm belongs to a financial and insurance sector and 0 , otherwise; CHIN is dummy that takes the value 1 if the firm belongs to a chemical industry sector and 0 , otherwise; RE is dummy that takes the value 1 if the firm belongs to a real estate sector and 0 , otherwise; MASSM is dummy that takes the value 1 if the firm belongs to a mass media sector and 0 , otherwise; BMI is dummy that takes the value 1 if the firm belongs to a basic metal industries sector and 0, otherwise; OPI is dummy that takes the value 1 if the firm belongs to another processing industries and 0 , otherwise; MPI is dummy that takes the value 1 if the firm belongs to a metal processing industries sector and 0 , otherwise and OTHR is dummy that takes the value 1 if the firm belong to other sectors and 0 , otherwise. $* \mathrm{p}<0.1 ; * * \mathrm{p}<0.05 ; * * * \mathrm{p}<0.01$ 
Table 6

Results of the Tobit regression for pressure-sensitive female directors and pressure-resistant female directors on boards

\begin{tabular}{|c|c|c|c|}
\hline Variables & $\begin{array}{c}\text { Expected } \\
\text { Sign }\end{array}$ & $\begin{array}{c}\text { Model } 2 \\
\text { (Estimated } \\
\text { coefficient } \\
\text { (p.value) }\end{array}$ & $\begin{array}{c}\text { Model } 3 \\
\text { Estimated } \\
\text { coefficient } \\
\text { (p.value) }\end{array}$ \\
\hline WSENSIT & - & $\begin{array}{c}0.007 \\
(0.904)\end{array}$ & \\
\hline WRESIST & + & & $\begin{array}{c}0.023 * * * \\
(0.001)\end{array}$ \\
\hline BINDEP & + & $\begin{array}{c}0.014 * * * \\
(0.000)\end{array}$ & $\begin{array}{c}0.015^{* * *} \\
(0.000)\end{array}$ \\
\hline LEV & + & $\begin{array}{c}0.001 \\
(0.471)\end{array}$ & $\begin{array}{c}0.001 \\
(0.438)\end{array}$ \\
\hline ROA & + & $\begin{array}{c}0.006 * * \\
(0.040)\end{array}$ & $\begin{array}{c}0.007 * * \\
(0.017)\end{array}$ \\
\hline SIZE & + & $\begin{array}{c}0.466 * * * \\
(0.000)\end{array}$ & $\begin{array}{c}0.469^{* * * *} \\
(0.000)\end{array}$ \\
\hline BSIZE & + & $\begin{array}{c}0.033 * * \\
(0.028)\end{array}$ & $\begin{array}{c}0.030 * * \\
(0.045)\end{array}$ \\
\hline INSOWN & - & $\begin{array}{c}-0.009 * * * \\
(0.001)\end{array}$ & $\begin{array}{c}-0.010 * * * \\
(0.000)\end{array}$ \\
\hline CGCM & $+/-$ & $\begin{array}{c}0.450 \\
(0.139)\end{array}$ & $\begin{array}{c}0.367 \\
(0.227)\end{array}$ \\
\hline COMER & $+/-$ & $\begin{array}{c}0.822 * * * \\
(0.002)\end{array}$ & $\begin{array}{c}0.768^{* * *} \\
(0.004)\end{array}$ \\
\hline CONST & $+/-$ & $\begin{array}{c}0.911^{* * * *} \\
(0.000)\end{array}$ & $\begin{array}{c}0.849 * * * \\
(0.001)\end{array}$ \\
\hline EW & $+/-$ & $\begin{array}{c}0.730 * * * \\
(0.007)\end{array}$ & $\begin{array}{c}0.737 * * * \\
(0.006)\end{array}$ \\
\hline FININS & $+/-$ & $\begin{array}{l}-0.084 \\
(0.804)\end{array}$ & $\begin{array}{l}-0.045 \\
(0.891)\end{array}$ \\
\hline CHIN & $+/-$ & $\begin{array}{c}0.731 * * \\
(0.022)\end{array}$ & $\begin{array}{c}0.751 * * \\
(0.018)\end{array}$ \\
\hline RE & $+/-$ & $\begin{array}{c}-1.323 * * * \\
(0.000)\end{array}$ & $\begin{array}{c}-1.318^{* * *} \\
(0.000)\end{array}$ \\
\hline MASSM & $+/-$ & $\begin{array}{c}0.979 * * * \\
(0.001)\end{array}$ & $\begin{array}{c}0.883 * * * \\
(0.002)\end{array}$ \\
\hline BMI & $+/-$ & $\begin{array}{c}0.798 * * * \\
(0.006)\end{array}$ & $\begin{array}{c}0.749 * * * \\
(0.009)\end{array}$ \\
\hline OPI & $+/-$ & $\begin{array}{c}0.683 * * * \\
(0.006)\end{array}$ & $\begin{array}{c}0.689 * * * \\
(0.005)\end{array}$ \\
\hline MPI & $+/-$ & $\begin{array}{c}0.249 \\
(0.340)\end{array}$ & $\begin{array}{c}0.238 \\
(0.356)\end{array}$ \\
\hline OTHR & $+/-$ & $\begin{array}{c}0.622 * * \\
(0.021)\end{array}$ & $\begin{array}{c}0.607 * * \\
(0.023)\end{array}$ \\
\hline $\begin{array}{c}\mathrm{F} \\
\mathrm{R}^{2}\end{array}$ & & $\begin{array}{c}679.07 * * * \\
32.75 \%\end{array}$ & $\begin{array}{c}690.54 * * * \\
33.31 \%\end{array}$ \\
\hline
\end{tabular}

CSR_Index is the dependent variable, measured as the sum of the score of the three areas analysed divided by 3; WSENSIT is the proportion of pressure-sensitive institutional female directors (i.e., banks and insurance companies); WRESIST is the proportion of pressure-resistant institutional female directors (i.e., investment funds); INDEP is the proportion of independent directors on the board; BDSIZE is the number of directors on boards; LEV is the debt over total assets; ROA is the operate income before interests and taxes over total assets; SIZE is the $\log$ of total assets; BSIZE is the number of member on boards; INSOWN is the Percentage of shares held by insiders (directors) on board; TR is dummy that takes the value 1 if the firm belongs to a transport sector and 0 , otherwise; CGCM is dummy that takes the value 1 if the firms belong to a cement, glass and construction materials sector and 0 , otherwise; COMER is dummy that takes the value 1 if the firm belongs to a commerce and other services sector and 0, otherwise; CONST is dummy that takes the value 1 if the firm belongs to a construction sector and 0, otherwise; EW is dummy that takes the value 1 if the firm belongs to an energy and water sector and 0 , otherwise; FININS is dummy that takes the value 1 if the firm belongs to a financial and insurance sector and 0 , otherwise; CHIN is dummy that takes the value 1 if the firm belongs to a chemical industry sector and 0 , otherwise; RE is dummy that takes the value 1 if the firm belongs to a real 
estate sector and 0, otherwise; MASSM is dummy that takes the value 1 if the firm belongs to a mass media sector and 0 , otherwise; BMI is dummy that takes the value 1 if the firm belongs to a basic metal industries sector and 0 , otherwise; OPI is dummy that takes the value 1 if the firm belongs to another processing industries and 0, otherwise; MPI is dummy that takes the value 1 if the firm belongs to a metal processing industries sector and 0 , otherwise and OTHR is dummy that takes the value 1 if the firm belong to other sectors and 0 , otherwise. $* \mathrm{p}<0.1 ; * * \mathrm{p}<0.05 ; * * * \mathrm{p}<0.01$ 